\author{
EDMUND HAJDUK $^{1 *}$, STANISŁAW WŁAŚNIEWSKI ${ }^{1}$, EWA SZPUNAR-KROK ${ }^{2}$ \\ ${ }^{1}$ Department of Soil Science, Chemistry of Environment and Hydrology, University of Rzeszów \\ $8 B$ Zelwerowicza Str., 35-601 Rzeszów, Poland \\ 2 Department of Plant Production, University of Rzeszów, 4 Zelwerowicza Str., 35-601 Rzeszów, Poland
}

\title{
Influence of legume crops on content of organic carbon in sandy soil
}

\begin{abstract}
The paper presents the results of a 3-year field experiment designed to evaluate the content of organic carbon in brown soil (Haplic Cambisol Dystric) developed from a light loamy sand under legumes cultivation. Experimental factors were: species of legume crop (colorful-blooming pea (Pisum sativum), chickling vetch (Lathyrus sativus), narrow-leafed lupin (Lupinus angustifolius), methods of legumes tillage (legumes in pure culture and in mixture with naked oats) and mineral $\mathrm{N}$ fertilization $(0,30,60,90$ $\left.\mathrm{kg} \mathrm{N} \cdot \mathrm{ha}^{-1}\right)$. Cultivation of legumes on sandy soil did not result in an increase of organic carbon content in the soil after harvest as compared to the initial situation, i.e. 7.39 vs. $7.76 \mathrm{~g} \cdot \mathrm{kg}^{-1}$ dry matter (DM), on average, respectively. However, there was the beneficial effect of this group of plants on soil abundance in organic matter, the manifestation of which was higher content of organic carbon in soils after legume harvest as compared to soils with oats grown $\left(7.21 \mathrm{~g} \cdot \mathrm{kg}^{-1} \mathrm{DM}\right.$, on average $)$. Among experimental crops, cultivation of pea exerted the most positive action to organic carbon content $\left(7.58 \mathrm{~g} \cdot \mathrm{kg}^{-1}\right.$, after harvest, on average), whereas narrow-leaved lupin had the least effect on organic carbon content $\left(7.23 \mathrm{~g} \cdot \mathrm{kg}^{-1}\right.$, on average). Pure culture and greater intensity of legume cultivation associated with the use of higher doses of mineral nitrogen caused less reduction in organic carbon content in soils after harvest.
\end{abstract}

Keywords: soil organic carbon, legumes, nitrogen fertilization

\section{INTRODUCTION}

The soil organic matter, especially its fraction referred to as humus, is one of the fundamental factors influencing the soil properties and fertility (Malhi and Lemke 2007, Pranagal 2004, Ryan et al. 2008 ). The plant material in various stages of decomposition and conversion is a source of the soil organic matter, both in crop fields, as well as in forest soils (Kondratowicz-Maciejewska et al. 2012). In agricultural soils, its main source are natural and organic fertilizers as well as crop residues. Deepening organic carbon deficit in soils is a very common problem associated with intensive crop production under conditions of limited use of organic fertilizers (Pranagal 2004). It is estimated that most of soils have lost $30-75 \%$ of the organic carbon resulting from cultivation (Lal et al. 2007). Deficit of the soil organic matter (SOM) is the largest, the better is the soil aeration (Baledesdent et al. 2000, Gonet 2007), which is a function of particle size composition, soil structure, moisture conditions, and the frequency and type of tillage applied. Hence, to maintain the fertility and productivity of soils, any action aimed at in preservation or increasing their abundance in organic matter, is undertaken, including the use of appropriate crop rotations (Fortuna et al. 2008, Ryan et al. 2008). Moreover, it promotes the carbon sequestration and thus reduces the greenhouse effect (Derner and Schuman 2007, Lal et al. 2007).

One of the methods to counteract adverse changes of soil property is to increase the participation of humus-forming crops in a rotation. Many authors indicate that the cultivation of legumes (Papilionaceae) favors the accumulation of humus in the soil and also increases the soil nitrogen pool (Drinkwater et al. 1998, Fortuna et al. 2008, Odunze 2003, Podleśny 2005, Yadav et al. 2003, Rutkowska and Pikuła 2013). Due to the good chemical composition, legumes are an important component of high-protein feed, as well as a valuable component of the human diet. However, as far, legumes make up a small part in crop structure in Poland (about 2.5\%), whereas in Western Europe it reaches 5\% (Podleśny 2005).

The aim of the study was to evaluate the effect of selected legume crops grown in a pure stand and in mixtures with oats on sandy soils, on the content of organic carbon in soil.

\section{MATERIALS AND METHODS}

The strict field experiment in the triple-factorial system by means of randomized sub-blocks (splitsplit-plot) in 4 replicates was carried out in Lubliniec Nowy near Lubaczów between 2003 and 2005. The experiment was conducted on light dystrophic soil 
(Haplic Cambisol Dystric) developed from light loamy sand on loose sand deposited on a depth of 50 $\mathrm{cm}$, of middle quality (good rye complex and quality class IV b). The area of harvesting plots was $16 \mathrm{~m}^{2}$. Winter rye was the forecrop. Experimental factors were as follows:

(I) - species of legume crop: colorful-blooming pea ('Sokolik' cv. at density of 125 plants $\cdot \mathrm{m}^{-2}$, chickling vetch ('Derek' cv. -80 plants $\cdot \mathrm{m}^{-2}$ ), narrow-leafed lupin ('Sonet' - 125 plants $\cdot \mathrm{m}^{-2}$ );

(II) - methods of legumes tillage: legumes in pure culture and in mixture (at proportion of $50 \%$ of norms recommended for their pure culture) with naked oats ('Bajka' cv. -550 plants $\cdot \mathrm{m}^{-2}$ );

(III) - levels of $\mathrm{N}$ fertilization: $\mathrm{A}$ - control (without nitrogen nutrition); $\mathrm{B}$ - feeding with $30 \mathrm{~kg} \mathrm{~N} \cdot \mathrm{ha}^{-1}$; $\mathrm{C}$ - feeding with $60 \mathrm{~kg} \mathrm{~N} \cdot \mathrm{ha}^{-1} ; \mathrm{D}$ - feeding with 90 $\mathrm{kg} \mathrm{N} \cdot \mathrm{ha}^{-1}$.

Nitrogen fertilization was performed after sowing. In low-cost objects (B), nitrogen nutrition was applied in full in spring with a dose of $30 \mathrm{~kg} \mathrm{~N} \cdot \mathrm{ha}^{-1}$ at the shooting phase of cereals. With the mediumcost growing level, the nitrogen fertilization was divided into equal doses: $30 \mathrm{~kg} \mathrm{~N}$ in spring and $30 \mathrm{~kg}$ $\mathrm{N} \cdot \mathrm{ha}^{-1}$ at the shooting phase of cereals, whereas at the high-cost (D) $-50 \mathrm{~kg} \mathrm{~N}$ was applied in spring and 40 $\mathrm{kg} \mathrm{N} \cdot \mathrm{ha}^{-1}$ at the shooting phase of cereals. Phosphoruspotassium nutrition was constant at the level of $80 \mathrm{~kg}$ $\mathrm{P}_{2} \mathrm{O}_{5} \cdot \mathrm{ha}^{-1}$ (in the form of triple superphosphate $-46 \%$ ) and $120 \mathrm{~kg} \mathrm{~K}_{2} \mathrm{O} \cdot \mathrm{ha}^{-1}$ (in the form of potassium salt $60 \%)$.

Each year, soil samples for laboratory analyses were collected from the topsoil of individual objects after crop harvest using the sampling stick. The organic carbon content in soil samples was determined by means of the Tiurin method. General physicochemical properties of soils and available forms of macronutrients were determined by methods generally accepted in the agricultural-chemical laboratories (Ostrowska et al. 1991). Basic physicochemical and chemical properties of soils before experiment are shown in Table 1.

The results obtained were subject to fundamental statistical processing (using Statistica 8 software) by calculating arithmetic mean, standard deviation, and straight correlation coefficients between means. The triple-factorial variance analysis was also performed by calculating the least square differences $\left(\mathrm{LSD}_{\mathrm{p}=0.05}\right)$ between means applying Tukey procedure for experiments from particular regions, although these differences were statistically insignificant.

\section{RESULTS AND DISCUSSION}

The average content of organic carbon in soils after the legumes cultivation was $7.39 \mathrm{~g} \cdot \mathrm{kg}^{-1} \mathrm{DM}$ of soil, which was lower content in comparison with the situation before growing $\left(7.76 \mathrm{~g} \cdot \mathrm{kg}^{-1} \mathrm{DM}\right.$, on average) (Table 2). Therefore, the experiment results did not confirm the observations of many authors that cultivation of legumes increases the content of this element in soils after harvest (Adeboye et al. 2006, Bałuch and Benedycki 2004, Gaweł 2011, Ryan et al. 2008). Kirchman et al. (2007) compared the influence of organic (taking into account the legumes) and conventional tillage on the soil properties. The authors (Kirchman et al. 2007) recorded the decrease in organic carbon content in soils of both systems, but much lesser in organic variant. It can be assumed that the mineralization of organic matter in sandy soil
TABLE 1. Selected properties of the examined soil before the experiment

\begin{tabular}{|c|c|c|c|}
\hline Parameter & Unit & Average & Range \\
\hline$\%$ particles of diameter $<0.02 \mathrm{~mm}$ & $\%$ & 15 & $11-20$ \\
\hline $\mathrm{pH}_{\mathrm{H} 20}$ & - & 6.12 & $5.60-6.42$ \\
\hline $\mathrm{pH}_{\mathrm{KCl}}$ & - & 5.21 & $4.96-5.56$ \\
\hline Exchangeable acidity (Hw) & $\mathrm{cmol}(+) \cdot \mathrm{kg}^{-1} \mathrm{DM}$ & 0.29 & $0.20-0.31$ \\
\hline Hydrolytic acidity (Hh) & $\mathrm{cmol}(+) \cdot \mathrm{kg}^{-1} \mathrm{DM}$ & 1.95 & $1.95-1.96$ \\
\hline Base exchange capacity (BEC) & $\operatorname{cmol}(+) \cdot \mathrm{kg}^{-1} \mathrm{DM}$ & 3.3 & $1.81-4.80$ \\
\hline Cation exchange capacity (CEC) & $\mathrm{cmol}(+) \cdot \mathrm{kg}^{-1} \mathrm{DM}$ & 5.26 & $3.76-6.75$ \\
\hline Base saturation (BS) & $\%$ & 59.6 & $48.1-71.1$ \\
\hline \multicolumn{4}{|l|}{ Total content: } \\
\hline Organic carbon (Corg) & $\mathrm{g} \cdot \mathrm{kg}^{-1} \mathrm{DM}$ & 7.76 & $7.62-7.90$ \\
\hline $\mathrm{N}$ & $\mathrm{g} \cdot \mathrm{kg}^{-1} \mathrm{DM}$ & 0.65 & $0.64-0.67$ \\
\hline $\mathrm{P}$ & $\mathrm{g} \cdot \mathrm{kg}^{-1} \mathrm{DM}$ & 0.51 & $0.51-0.51$ \\
\hline K & $\mathrm{g} \cdot \mathrm{kg}^{-1} \mathrm{DM}$ & 1.51 & $1.25-1.77$ \\
\hline $\mathrm{Ca}$ & $\mathrm{g} \cdot \mathrm{kg}^{-1} \mathrm{DM}$ & 1.23 & $1.11-1.35$ \\
\hline $\mathrm{Mg}$ & $\mathrm{g} \cdot \mathrm{kg}^{-1} \mathrm{DM}$ & 0.67 & $0.53-0.80$ \\
\hline \multicolumn{4}{|l|}{ Content of available forms } \\
\hline $\mathrm{P} \quad$ (P_av) & $\mathrm{mg} \mathrm{P}_{2} \mathrm{O}_{5} \cdot \mathrm{kg}^{-1} \mathrm{DM}$ & 164 & $156-173$ \\
\hline $\mathrm{K} \quad\left(\mathrm{K}^{-}\right.$av $)$ & $\mathrm{mg} \mathrm{K}_{2} \mathrm{O} \cdot \mathrm{kg}^{-1} \mathrm{DM}$ & 111 & $79-143$ \\
\hline $\operatorname{Mg}(\mathrm{Mg}$ av $)$ & $\mathrm{mg} \mathrm{Mg} \cdot \mathrm{kg}^{-1} \mathrm{DM}$ & 41 & $31-52$ \\
\hline
\end{tabular}




\begin{tabular}{|c|c|c|c|c|c|c|c|c|c|c|c|}
\hline \multirow{3}{*}{$\begin{array}{r}\text { TABLE } 2 . \\
\text { Organic carbon } \\
\text { content in soils } \\
\text { before beginning } \\
\text { of experiment }\end{array}$} & \multirow[t]{3}{*}{ Plant } & \multicolumn{4}{|c|}{ Range } & \multicolumn{2}{|c|}{ Mean } & \multicolumn{2}{|c|}{ Median } & \multicolumn{2}{|c|}{$\begin{array}{l}\text { Variability } \\
\text { coefficient }[\%]\end{array}$} \\
\hline & & \multicolumn{2}{|c|}{ minimum } & \multicolumn{2}{|c|}{ maximum } & \multirow[b]{2}{*}{$X$} & \multirow{3}{*}{$\begin{array}{l}\mathrm{Y} \\
-7.39\end{array}$} & \multirow{3}{*}{$\frac{X}{7.76}$} & \multirow{3}{*}{$\begin{array}{l}\mathrm{Y} \\
-7.34\end{array}$} & \multirow{3}{*}{$\frac{X}{2.6}$} & \multirow{3}{*}{$\begin{array}{c}\mathrm{Y} \\
-17.4 \\
\end{array}$} \\
\hline & & X & $\mathrm{Y}$ & $\mathrm{X}$ & $\mathrm{Y}$ & & & & & & \\
\hline$(\mathrm{X})$ and after & Legumes & 7.62 & 4.74 & 7.90 & 10.5 & 7.76 & & & & & \\
\hline$\left(\mathrm{g} \cdot \mathrm{kg}^{-1} \mathrm{DM}\right)$ & Outline & & 5.52 & & $\overline{10.2}$ & & $\overline{7.21}$ & & 6.93 & & 17.5 \\
\hline
\end{tabular}

occurred at faster rate during the study period than organic matter gains from crop residues. Experiment involving the cultivation of legumes on silty soil carried out in an identical period (Hajduk et al. 2013) revealed an increase in the amount of organic carbon after harvest. This is confirmed by the observations of Gawel (2011), who noted that the organic matter reproduction rate, in the case of cultivation of legumes and their mixtures, was positive and the greater the heavier soil. Alegre et al. (2004) draw attention to the impact of environmental moisture conditions on the return of organic matter to the soil and grown with woody forms of legumes under conditions of semi-arid climate. Perhaps, less water in sandy soils (compared to dusty ones) affected the lesser accumulation of organic carbon. It should be noted, however, that the content of organic carbon in the experimental soils after harvest of oats grown under similar conditions, was even lower $-7.21 \mathrm{~g} \cdot \mathrm{kg}^{-1} \mathrm{DM}$, on average, which showed that the cultivation of legumes reduces the losses of organic matter as a result of the cultivation (Table 2). Similarly, the long-term study conducted by Rutkowska and Pikuła (2013) at Grabów (Poland) on soil classified as light loamy and sand texture showed that the most important factor which stabilizes organic carbon content in agricultural soils was crop rotation with legumes.

Species of plant grown can significantly differentiate the organic matter content in the soil (Alegre et al. 2004, Bałuch and Benedycki 2004, Hajduk et al. 2013). Among the experimental crops, the pea cultivation had the most advantageous effect on the content of organic matter in soil after harvest $\left(7.58 \mathrm{~g} \mathrm{C} \cdot \mathrm{kg}^{-1} \mathrm{DM}\right.$, on average), whereas lupin - relatively the worst effect on the content of organic matter $\left(7.23 \mathrm{~g} \mathrm{C} \cdot \mathrm{kg}^{-1}\right.$ $\mathrm{DM}$, on average). However, differences between means were statistically insignificant (Table 3). For each of the cultivated legume species, the pure culture left more organic matter in the soil as compared to their mixtures with oats. The smallest difference between the organic carbon content of in soil after cultivation in pure culture and mixes with oats was observed for the pea. According to Gaweł (2011), mixtures of fine-grain legumes with grasses provide $25-27 \%$ more crop residues than legumes in the pure culture.
TABLE 3. The influence of legume species, tillage mode and the level of tillage intensity on organic carbon content in sandy soil $\left(\mathrm{g} \cdot \mathrm{kg}^{-1} \mathrm{DM}\right)$

\begin{tabular}{|c|c|c|c|c|c|c|}
\hline \multirow{2}{*}{$\begin{array}{l}\text { Plant species } \\
\text { (I) }\end{array}$} & \multirow{2}{*}{$\begin{array}{l}\text { Tillage } \\
\text { mode } \\
\text { (II) }\end{array}$} & \multicolumn{4}{|c|}{ Level of intensity of tillage (III) } & \multirow{2}{*}{$\begin{array}{l}\text { Average } \\
\text { without } \\
\text { regard on } \\
\text { the level } \\
\text { of the tillage } \\
\text { intensity }\end{array}$} \\
\hline & & $\mathrm{A}$ & B & $\mathrm{C}$ & $\mathrm{D}$ & \\
\hline \multirow[t]{3}{*}{ Pea seeds } & $P$ & 7.06 & 7.42 & 7.88 & 7.98 & 7.58 \\
\hline & $\mathrm{M}$ & 7.84 & 7.52 & 7.50 & 7.43 & 7.57 \\
\hline & Mean & 7.45 & 7.47 & 7.69 & 7.71 & 7.58 \\
\hline \multirow[t]{3}{*}{ Chickling vetch } & $\mathrm{P}$ & 7.32 & 7.43 & 7.47 & 7.48 & 7.43 \\
\hline & M & 7.10 & 7.27 & 7.30 & 7.34 & 7.25 \\
\hline & Mean & 7.21 & 7.35 & 7.38 & 7.41 & 7.34 \\
\hline \multirow{3}{*}{$\begin{array}{l}\text { Narrow-leaved } \\
\text { lupine }\end{array}$} & $\mathrm{P}$ & 7.34 & 7.39 & 7.27 & 7.31 & 7.33 \\
\hline & M & 7.02 & 7.14 & 7.07 & 7.29 & 7.13 \\
\hline & Mean & 7.18 & 7.27 & 7.17 & 7.30 & 7.23 \\
\hline \multirow[t]{2}{*}{ Mean } & $\mathrm{P}$ & 7.24 & 7.42 & 7.54 & 7.59 & 7.45 \\
\hline & M & 7.32 & 7.31 & 7.29 & 7.35 & 7.32 \\
\hline
\end{tabular}

Without regard on species and the way of tillage

\begin{tabular}{|c|c|c|c|c|c|c|}
\hline Mean & & 7.28 & 7.36 & 7.41 & 7.47 & 7.39 \\
\hline \multirow{2}{*}{$\begin{array}{l}\text { LSD } p=0.05 \\
\text { for factor: }\end{array}$} & I-r.n. & II-r.n & \multicolumn{4}{|c|}{ III- r.n. } \\
\hline & \multicolumn{6}{|c|}{ IxII- r.n. IIxI-r.n. IxIII- r.n. IIxIII- r.n. IxIIxIII-r.n. } \\
\hline
\end{tabular}

r.n. - statistically insignificant differences $(\alpha=0.05), P$ - pure culture, $\mathrm{M}$ - in mixtures with barley, A - control (without nitrogen nutrition); $\mathrm{B}$ - feeding with $30 \mathrm{~kg} \mathrm{~N} \cdot \mathrm{ha}^{-1} ; \mathrm{C}$ - feeding with $60 \mathrm{~kg} \mathrm{~N} \cdot \mathrm{ha}^{-1}$; $\mathrm{D}$ - feeding with $90 \mathrm{~kg} \mathrm{~N} \cdot \mathrm{ha}^{-1}$.

Mercik et al. (2005) noted that the content of Corg, under conditions of long-term fertilization experiments, increases as a result of intensive mineral nutrition both with and without application of manure. Legumes, due to symbiosis with Rhizobium bacteria, are capable of fixing atmospheric nitrogen. However, this cooperation is effective at a later stage of the growing season. Hence, some positive effect of small doses of mineral nitrogen applied into the soil on the yield of legumes was observed (Sparrow and Panciera 2001). In the present experiment, impact of three rates of nitrogen fertilization $\left(0,30,60\right.$, and $\left.90 \mathrm{~kg} \mathrm{~N} \cdot \mathrm{ha}^{-1}\right)$ on organic carbon resources in soils after crop harvest was analyzed and the increasing trend was recorded (Table 3): 7.28, 7.36, 7.41, $7.47 \mathrm{~g} \mathrm{C} \cdot \mathrm{kg}^{-1} \mathrm{DM}$, respectively. Ryan et al. (2008) found a similar tendency 
in crop rotation with legumes. In the experiment involving 3 legume plants (soybean, cowpea, Centrosema pascuorum), Adeboye et al. (2006) observed the highest content of organic carbon in the soil at a dose of $20 \mathrm{~kg} \mathrm{~N} \cdot \mathrm{ha}^{-1}$. These authors also observed a tendency to reduce the amount of water-soluble organic carbon fraction along with increasing the nitrogen fertilization. Adeboye et al. (2006) also noticed the largest amount of soil microbial biomass $\mathrm{C}$ in variant without nitrogen nutrition. On the other hand, Bałuch and Benedycki (2004) recorded various effect of mineral fertilization on the content of organic matter in soil during the five-year experiment with legume-grass mixtures. Usually the most preferable effect in this case, was shown by the dose $60 \mathrm{~kg} \mathrm{~N} \cdot \mathrm{ha}^{-1}$.

The present study revealed statistically significant positive correlations between the organic carbon content and hydrolytic acidity of the soil, the sum of exchangeable alkali or the capacity of the soil sorption complex relative to the cations (Table 4). Also, contents of the total and available forms of potassium and magnesium were proportional to the amount of organic $\mathrm{C}$ in soil after the cultivation of legumes. Adeboye et al. (2006) found positive correlation between the content of organic carbon and soil $\mathrm{pH}$ in an experiment involving legumes. The present experiment did not reveal such a relationship, however contents of total and available forms of potassium and magnesium was proportional to the amount of organic $\mathrm{C}$ in the soil after the legumes growing. This highlights the beneficial effect of legume crops on physicochemical and chemical properties of studied soils. On the other hand, what is surprising, a negative and statistically significant correlation between the amount of organic carbon and total nitrogen in experimental soils, was disclosed. It should be emphasized that this is a result of a significant enrichment of soils with nitrogen at decreasing the amount of organic carbon. This results a substantial narrowing of $\mathrm{C} / \mathrm{N}$ ratio, which highly improves the availability of nitrogen for plants.

TABLE 4. Coefficients of straight correlation among organic carbon content in soil and some properties of soils $(n=144$, $\alpha=0.05$ )

\begin{tabular}{lllllll}
\hline $\mathrm{pH}_{2} \mathrm{KCl}$ & $\mathrm{pH} \mathrm{H}_{2} \mathrm{O}$ & $\mathrm{Hw}$ & $\mathrm{BEC}$ & $\mathrm{CEC}$ & $\mathrm{BS}$ & $\mathrm{N}$ \\
n.s. & n.s. & n.s. & 0.302 & 0.421 & $\mathrm{n} . \mathrm{s}$. & -0.300 \\
\hline $\mathrm{P} \_$av & $\mathrm{P}$ & $\mathrm{K} \_\mathrm{av}$ & $\mathrm{K}$ & $\mathrm{Mg}$ av & $\mathrm{Mg}$ & $\mathrm{Ca}$ \\
n.s. & n.s. & 0.563 & 0.538 & 0.772 & 0.781 & n.s. \\
\hline
\end{tabular}

n.s. - insignificant.

\section{CONCLUSIONS}

1. Cultivation of legumes on sandy soil did not result in a considerable increase of organic carbon content in the soil after harvest as compared to the initial situation. However, there was the beneficial effect of this group of plants on soil abundance in organic matter, the manifestation of which was higher content of organic carbon in soils after legume harvest as compared to soils with oats grown.

2. Among experimental crops, cultivation of pea exerted the most positive action to organic carbon content, while that of narrow-leaved lupin - the least.

3. Pure culture and greater intensity of legume cultivation associated with the use of higher doses of mineral nitrogen, caused less reduction in organic carbon content in soils after harvest.

\section{REFERENCES}

Adeboye M.K.A., Iwuafor E.N.O., Agbenin J.O., 2006. The effects of crop rotation and nitrogen fertilization on soil chemical and microbial properties in a Guinea Savanna Alfisol of Nigeria. Plant and Soil, 281: 97-107.

Alegre J., Alonso-Blázquez N., de Andrés E.F., Tenorio J.L., Ayerbe L., 2004. Revegetation and reclamation of soils using wild leguminous shrubs in cold semiarid Mediterranean conditions: Litterfall and carbon and nitrogen returns under two aridity regimes. Plant and Soil, 263: 203-212.

Baledesdent J., Chenu C., Balabane M., 2000. Relationship of soil organic matter dynamics to physical protection and tillage. Soil and Tillage Research, 53(3-4): 215-230.

Bałuch A., Benedycki S., 2004. Effects of legume-grass mixtures and mineral fertilization on soil fertility. Annales UMCS, Sec. E, 59 (1): 441-448 (in Polish).

Derner J.D., Schuman G.E., 2007. Carbon sequestration and rangelands: A synthesis of land management and precipitation effects. Journal of Soil \& Water Conservation, 62 (2): 77-85.

Drinkwater L.E., Wagoner P., Sarrantonio M., 1998. Legumebased cropping system have reduced carbon and nitrogen losses. Nature, 369: 262-265.

Fortuna A., Blevins R.L., Frye W.W., Grove J., Cornelius P., 2008. Sustaining Soil Quality with Legumes in No-Tillage Systems. Communications in Soil Science \& Plant Analysis, 39 (11/12): 1680-1699.

Gaweł E., 2011. The role of fine-grained legume plants in a farm. Water-Environment-Rural areas, 11 (3): 73-91 (in Polish).

Gonet S.S., 2007. Organic matter in the European Union thematic strategy on soil protection. Roczniki Gleboznawcze - Soil Science Annual, 58(3/4): 15-26 (in Polish).

Hajduk E., Kaniuczak J., Szpunar-Krok E., 2013. Content of organic carbon in brown soil made of loess after cultivation of papilionaceous plants. Acta Carpathica, 3: 25-30. (in Polish).

Kirchman H., Bergstrom L., Mattsson L., Gesslein S., 2007. Comparison of Long-Term Organic and Conventional Crop-Livestock System on a Previously Nutrient Depleted Soil in Sweden. Agronomy Journal, 99 (4): 960-972. 
Kondratowicz-Maciejewska K., Kobierski M., Murawska A., 2012. Effect of brunic arenosols use on selected physicochemical properties in organic matter. Roczniki Gleboznawcze Soil Science Annual, 63(2): 19-24 (in Polish).

Lal R., Follett R.F., Stewart B.A., Kimble J.M., 2007. Soil carbon sequestration to mitigate climate change and advance food security. Soil science, 172 (12): 943-956.

Malhi S.S., Lemke R., 2007. Tillage, crop residue and $\mathrm{N}$ fertilizer effects on crop yield, nutrient uptake, soil quality and nitrous oxide gas emissions in a second 4 -yr rotation cycle. Soil \& Tillage Research, 96: 269-283.

Mercik S., Stępień M., Stępień W., Sosulski T., 2005. Dynamics of organic carbon content in soil depending on long-term fertilization and crop rotation. Roczniki Gleboznawcze - Soil Science Annual, 56(3/4): 19-24.

Odunze A.C., 2003. Effect of Forage Legume Incorporation on Selected Soil Chemical Properties in the Northern Guinea Savanna of Nigeria. Journal of Sustainable Agriculture, 22 (1): 101-112.

Ostrowska A., Gawliński A., Szczubiałka Z., 1991. Methods for analysis and evaluation of soils and plants. Catalogue of Wyd. Inst. Ochr. Środ., Warszawa: 324 pp. (in Polish).
Podleśny J., 2005. Legumes in Poland - perspectives for growing and seed utilization. Acta Agrophysica, 6(1): 213-224 (in Polish).

Pranagal J., 2004. The effect of tillage system on organic carbon content in the soil Annales UMCS, Sec. E, 59(1): 1-10.

Rutkowska A., Pikuła D., 2013. Effect of Crop Rotation and Nitrogen Fertilization on the Quality and Quantity of Soil Organic Matter. [In:] Soil Processes and Current Trends in Quality Assessment. (M.C. Hernandez Soriano, Editors) In Tech, Rijeka, Croatia: 249-267.

Ryan J., Masri S., Ibrkçi H., Singh M., Pala M., Harris H.C., 2008. Implications of Cereal-Based Crop Rotations, Nitrogen Fertilization, and Stubble Grazing on Soil Organic Matter in a Mediterranean-Type Environment. Turkish Journal of Agriculture \& Forestry, 32 (4): 289-297.

Sparrow S.D., Panciera M.T., 2001. Crop Yield and Soil Characteristics Following Various Cropping Regimes in Alaska. Acta Agriculturae Scandinavica, Section B, 51: 143-150.

Yadav R.L., Singh V.K., Dwivedi B.S., Shukla A.K., 2003. Wheat productivity and $\mathrm{N}$ use-efficiency as influenced by inclusion of cowpea as a grain legume in a rice-wheat system. Journal of Agricultural Science, 141 (2): 213-220.

\section{Wpływ uprawy roślin motylkowatych na ksztaltowanie zawartości węgla organicznego w glebie piaszczystej}

Streszczenie: W pracy przedstawiono wyniki 3-letniego doświadczenia polowego, którego celem była ocena zawartości węgla organicznego w glebie brunatnej dystroficznej, wytworzonej z piasku gliniastego lekkiego w warunkach uprawy roślin bobowatych. Czynnikami doświadczenia były: gatunek rośliny (groch barwnie kwitnący, lędźwian siewny, łubin wąskolistny), metody uprawy roślin strączkowych (rośliny strączkowe w siewie czystym oraz w mieszaninie z owsem) i nawożenie mineralne $\mathrm{N}(0,30,60,90 \mathrm{~kg}$ $\left.\mathrm{N} \cdot h \mathrm{a}^{-1}\right)$. Uprawa roślin motylkowatych na glebie piaszczystej nie spowodowała znacznego zwiększenia zawartości węgla organicznego w glebach po zbiorze plonów w porównaniu do stanu wyjściowego (średnio odpowiednio 7,39 i 7,76 g. $\mathrm{kg}^{-1} \mathrm{~s} . \mathrm{m}$.). Jednakże można zauważyć korzystny wpływ tej grupy roślin na zasobność gleb w materię organiczną, czego przejawem była wyższa zawartość węgla organicznego w glebach po zbiorze plonów roślin bobowatych w porównaniu do gleb obsianych owsem (średnio $7,21 \mathrm{~g} \cdot \mathrm{kg}^{-1}$ s.m.). Spośród uprawianych roślin najkorzystniej na kształtowanie zawartości Corg wpłynęła uprawa grochu siewnego (średnia po zbiorze plonów $7,58 \mathrm{~g} \cdot \mathrm{kg}^{-1}$ ), najmniej korzystnie uprawa łubinu wąskolistnego (średnio $7,23 \mathrm{~g} \cdot \mathrm{kg}^{-1}$ ). Siew czysty oraz większa intensywność uprawy roślin motylkowatych, związana z zastosowaniem większych dawek azotu mineralnego, powodowały w mniejszym stopniu obniżenie zawartości Corg w glebie po zbiorze plonów.

Stowa kluczowe: węgiel organiczny w glebie, rośliny motylkowate, nawożenie azotowe 